\title{
Banks' Governance, Capital Structure and Performance in Ghana
}

\author{
Anthony Adu-Asare Idun ${ }^{1}$, Joyce Arthur ${ }^{2}$, Patrick Tutu ${ }^{3}$ \\ ${ }^{1}$ School of Business, Universitu of Cape Coast, Ghana \\ E-mail:aidun@ucc.edu.gh \\ ${ }^{2,3}$ P. O. Box, AN 5183, Accra North, Ghana \\ E-mail: arthurjoycem@yahoo.com ${ }^{2}$. tutupatrick41@gmail.com ${ }^{3}$
}

https://doi.org/10.47963/jobed.2020.05

\begin{abstract}
The paper explores the mechanisms through which banks rely on good governance to attract more equity capital towards the improvement of their profitability. The study employed a panel data for twenty-nine commercial banks in Ghana between the years from 2003 to 2015, using the Generalized Method of Moments (GMM), Fixed Effects and Random Effects estimators. The results are robust notwithstanding the estimation method employed, that bank governance affects banks' performance in Ghana. Larger board size improves return on the banks' equity just as large proportion of directors with finance expertise induces bank performance. All estimates also show that equity funding has a negative and significant effect on bank performance. The paper also found evidence that good bank governance attracts equity capital which, in turn, induces greater profitability. The study recommends for managers and policymakers of banks to adopt policies that will position the banks to improve governance structure, to improve managerial expertise to drive bank performance. Admonitions to expand bank capitalisation should not be encouraged without recourse to the improvement in bank governance effectiveness.
\end{abstract}

Keywords: Bank governance, capitalization, Ghana bank performance 


\section{Introduction}

The banking sector plays an important role in the financial market of every economy and contributes to the development of economies (Demirgüç-Kunt, Feyen, \& Levine, 2012; Paradi \& Zhu, 2013). In Ghana, the banking sector contributed 4.7\%, 6.5\% and 8.4\% of GDP in 2012, 2013 and 2014, respectively (Ghana Statistical Service, 2015). Also, the sector expanded by $20.7 \%$ in 2014, which made the sector the largest growth within the service sector and the second-largest contribution to the service sector (PriceWaterHouse Cooper, 2014). Given the importance of banks in wealth creation, some studies have assessed bank efficiency and dynamic productivity, especially given the potential impact of competition, diversification, globalisation and technological advancements in the delivery of banking services (Liu, Lu, \& Lu, 2016; Amidu \& Wolfe, 2013; Casu, Ferrari, \& Zhao, 2013; Jaffry, Ghulam, \& Cox, 2013; Paradi \& Zhu, 2013; Fethi \& Pasiouras, 2010).

To better perform their financial intermediation roles, compete favourably in the globally competitive atmosphere, mitigate exposure to risk and drive growth, banks require effective governance mechanisms, which affect bank leverage and reduce agency problem (Berger \& Bouwman, 2013; Berger \& Di Patti, 2006). This assertion is backed by the recent Ghanaian banking crisis, which was partly due to bad board room decisions. In 2017, GCB Bank took over Capital Bank and UT Bank due to the banks' inability to meet regulatory requirements on non-performing loans (liquidity) and capital requirements. Reports from the Bank of Ghana attributed the situation to unpopular decisions by the boards of the banks to misappropriate Bank of Ghana's facilities meant to resuscitate their respective institutions. In the same token, five other banks were amalgamated into the new Consolidated Bank Ghana Limited due to mismanagement. As expected, people lost their job, families were displaced and the confidence in the banking sector went down momentarily. In the same token, effective December 2018, the Bank of Ghana enforced its new capital requirement threshold of GHS400,000,000. The banks are now more liquid to finance economic activities, but some banks were unable to meet the capital requirement. The increase in the capitalisation of the banks shows that equity capital can improve the performance of the banks by increasing their capital to withstand liquidity shocks. However, mismanagement of banks can reduce the ability of the banks to secure external funding.

Notwithstanding a decent number of studies on the impact of governance structure on performance globally (Min \& Bowman, 2015; Bokpin, 2013a; Kader, Adams, Hardwick, \& Kwon, 2014; Makokha, 2014; Reddy, Locke, \& Fauzi, 2013; Tornyeva \& Wereko, 2012), little attention has been given to the joint effect of governance and capital structures on performance, especially in the banking sector. Studies that concentrated on the influence of governance structure on firm performance did not explain how good bank governance structure can influence financing decisions towards the improvement of bank profitability (Bokpin \& Isshaq, 2009; Brailsford, Oliver, \& Pua, 2002; Öztekin, 2015). Other recent studies on the topic only attempted to identify the determinants of governance and capital structure (Abdullah \& Naser, 2015; Alipour, Mohammadi, \& Derakhshan, 2015; Köksal \& Orman, 2015; Ansari \& Bideskan, 2012; Öztekin \& Flannery, 2012). Besides, research that linked governance structure with the capital structure only attempted to identify determinants of capital structure and did not deeply explore the interaction of effect of governance structure and equity financing on the performance of banks in developing countries. This study seeks to examine whether good governance structures by the banks can induce them to attract equity financing to improve their performance.

The capital structure reflects the composition of the company's capital and can be expressed either as a ratio between debt and equity, as a ratio between internal and external financing sources, or either as a ratio between shortterm and long-term funding (Margaritis \& Psillaki, 2010). An optimal capital structure is one that strikes a balance between the degree of risk and the estimated rate of return; and thus maximises the market price of shares (Berger \& Bonaccorsi di Patti, 2006; Margaritis \& Psillaki, 2010).

Jensen and Meckling (1976) classified governance structure in terms of capital contributions that comprise inside investors (managers) and outside investors (debt holder and equity holder). Governance structure and capital structure are both key factors in research on agency cost theory. Due to the impact of capital structure and governance structure on firm leverage, researchers have developed a heightened interest in assessing their impact on performance. For instance, some researchers (e.g., Yulivan \& Hadi, 2016; Zhang, 2016; Wahba, 2014; Adewale \& Ajibola, 2013; Fosu, 2013; Salim \& Yadav, 2012; Tudose, 2012) investigated the impact of capital structure on firm performance, while others examined the relationship between governance structure and performance (Florackis, Kanas, \& Kostakis, 2015; Abor \& Biekpe, 2007).

This paper examines whether the governance structure of the banks enable them to attract equity capital to induce the performance of the banks. This study specifically investigates the impact of governance structure and capital structure on bank performance individually and also determines the interaction effect of governance structure and capital structure on the performance of banks in Ghana. We employed various panel regression models to achieve the objectives. The results show that whereas some governance mechanisms are detrimental to the performance of banks in Ghana, the banks can strengthen managerial competence to induce equity financing, which will, in turn, lead to greater shareholder wealth. The subsequent sections include literature review, research methods, discussions of the results and the conclusion of the paper. 


\section{Literature Review}

Governance Structure and Firm Performance

Corporate governance (CG) simply deals with mechanisms that enable suppliers of finance to the firm protect their interest and assure themselves of getting a reasonable return on their investment (Shleifer \& Vishny, 1997; Tomar $\&$ Bino, 2012). The principal foundation of corporate governance is agency theory, which indicates divergence of interest between managers and stockholders, hence the need for internal controls to check their opportunistic behaviour (Jensen \& Meckling, 1976). CG mechanisms are well addressed in developed countries, but practically non-existent in developing countries (Shleifer \& Vishny, 1997).

The economic dimension of corporate governance has sparked considerable research (see survey work by Haan \& Vlahu, 2016; Shleifer \& Vishny, 1997), intending to find effective governance mechanisms that can mitigate agency problems. Effective corporate governance leads to higher efficiency (Claessens \& Yurtoglu, 2013). However, to obtain the best from CG practices, Datar (2004) posits that it must be industry-specific to deal with peculiarities of the industry. Thus, the uniqueness of industry, like banking, warrants a separate CG structure in other to deal with issue peculiar to the industry (Mehran, Morrison, \& Shapiro, 2011; De Andres \& Vallelado, 2008).

The contemporary trend in corporate governance studies seeks to investigate if $\mathrm{CG}$ is significant in improving performance. These studies, in examining the nexus, have focused on different and specific dimensions of CG (Khiari, Karaa, \& Omri, 2007), providing interesting, but contrasting, conclusions. Board size is one of the most investigated dimensions of corporate governance in the literature. It is measured by the number of directors on the board (Pathan, 2009). Empirical evidence on the nexus between board size and performance is inconclusive. The argument is on whether large board size is better than a small board size, since it may affect effective monitoring (Singh \& Davidson III, 2003). In that regard, Poudel and Hovey (2012) find that larger boards lead to better efficiency among Nepal banks. Similarly, Abor and Fiador (2013) identify that board size has a significantly positive relationship with a high dividend pay-out. Tanna et al. (2011) also find a positive relationship between board size and performance. On the contrary, Naushad and Malik (2015) indicate that smaller boards in the GCC banking sector improve performance by effectively monitoring the management closely. Another interesting finding by Bokpin (2013b) is that while board size increases one aspect of performance (profitability), it reduces another (cost efficiency) among Ghanaian banks. Despite this trend in the literature, Darko, Aribi and Uzonwanne (2016) found no evidence of the impact of board size on the performance of listed firms in Ghana. According to Haan and Vlahu (2016), even though larger board size possesses more expertise and information, the cost associated with decision making increases with the board size, which can attenuate the gains from larger board sizes.

Board diversity is also another proxy of CG which, in this study, is the proportion of female directors on the board. Even though board diversity considers observable factors, such as gender, age, race, or nationality (Haan \& Vlahu, 2016), this study considers only gender diversity, particularly female directors on the board. According to Carter, Simkins, and Simpson (2003), board diversity promotes effective decision making and also facilitates innovation in the firm. Studies have provided evidence on the correlation between the proportion of female directors on board and performance. Carter et al. (2003) indicate a significant positive relationship between the fraction of women on the board and firm value. Other studies that found a positive relationship include Ntim, Lindop, and Thomas (2013), Darko et al. (2016), and Gitundu, Kisaka, Kiprop and Kibet (2016).

Agency theory posits that a board of diverse gender can improve board independence and enhance managerial monitoring. Similarly, the resource dependency theory suggests that boards of diverse gender can help associate the firm to its external environment and obtain the vital resource. Existing literature indicates that the diversity of group membership in any field of endeavour increases the exchange of ideas and discussion, and group performance. For example, Abdullah, Ismail and Izah (2017) indicate that a diversified and inclusive board are important to building quality boards in recent times, as affirmed by Davidson and Burke (2000), who contend that diversity is mostly considered because of its direct value-based contribution to an organisation, merit-based and organisationalenhancing values, rather than based on meeting affirmative action quotas or stakeholder representation. From the perspective of the agency theory, a more diversified board creates a balance of board membership, ensures that no individual can dominate the decision-making process. With the resource dependence theory, the presence of diversities of the board is in the interest of any organisation because more diversified boards link their organisations better to the environment, and generates strategic input (including social capital) to the organization (Bilimoria \& Wheeler, 2000).

Most prior literature concentrates on the gender perspective of diversity, which has resulted in highlighting the importance of having more women on the board (Sandfort \& Reddy, 2013). Gender is seen to be a much-contested diversity issue not only concerning the board of directors but also in areas of politics and other social disciplines (Kang et al., 2007). There have, therefore, been numerous advocacy and emphasis on the need for a more genderdiversified membership of the board. They suggest that women have critical symbolic values, both within and outside the company, indicating their high performance. It has been indicated that women directors can generate a more 
productive discourse by being able to question issues more freely than male directors (Bilimoria \& Wheeler, 2000). It is worth knowing that the directorship of women is equally based on a similar level of competence as required of male directors because women want to be known as directors (for their competence on board issues) first rather than as having a feminist agenda.

Studies suggest that earnings of companies were significantly higher for organisations with senior female executives (Kang et al., 2007). Therefore, involving women on boards and in top management leads to greater earnings and shareholder wealth (Sandfort \& Reddy, 2013). By the propositions of the resource dependency theory, corporate organisations can achieve greater transparency by including more women on the board, and this may, subsequently, translate into the firm's competitive advantage (David \& David, 2016). It has been suggested that female directors contribute to an organisation's competitive advantage firstly because they do not partake of the "old boys' network" makes them more independent and secondly because they tend to have a better understanding of the behaviour of customers, their needs, and opportunities for organisations in meeting those consumer needs. Previous studies justified gender-diversified board by suggesting that the direct proportion of women directors in boards induces firm financial performance (Mallin, Farag, \& Ow-Yong, 2014; Mersland \& Øystein Strøm, 2009). However, they indicate that the enforcement of gender quotas in the boardroom could rather reduce performance for firms with strong governance structure.

Board independence is another measure of CG, usually represented in the literature by the proportion of board that is non-executive (outside directors). It is well considered to effectively monitor managers, hence mitigating possible agency conflicts (Poudel \& Hovey, 2012). Pathan (2009) argues that because outside directors are concerned about their reputation, they effectively monitor managers' activities, thus reducing potential agency conflicts. Although Gitundu et al. (2016) and Darko et al. (2016) found a positive relationship between corporate governance and performance, Bhagat and Bolton (2008) in their research observed a negative relationship between board independence and performance. Similarly, Agoraki, Delis, and Staikouras (2010), and Wang, Lu and Lin (2012) identify an inverse relationship. Even though theoretical studies favour a positive relationship between board independence and performance, there exists the need to assess the scenario among universal banks in Ghana. Based on the argument that board independence improves managerial monitoring, which then enhances performance.

The audit committee is observed as an extension of risk management function (Tsorhe, Aboagye, \& KyereboahColeman, 2011). Their role is to identify and handle risk issues in complex organisations, like banks. The proper functioning of the committee can be guaranteed if they work independently of management influence, hence the need for an audit committee made up of outside board members. This study, as a result, focuses on the impact of an independent audit committee on performance.

Another variable of corporate governance mostly discussed in the literature is CEO duality. CEO duality describes the CEO (or an executive officer) of the firm being the chairman of the board (Haan \& Vlahu, 2016). Agency theory posits that if conflicts arising from agency relationship must be mitigated, then the CEO should not be the chairman of the board. Jensen and Meckling (1976) argue that the independence of the board will be compromised if the same person is CEO and board chairman. Contrary to the argument of agency theorists, stewardship theorists argue that managers being good stewards in the firm have more access to quality information about the firm, thus they will better steer the affairs of the firm if and when an executive manager is the chairman of the board. Several studies have examined the effect of CEO duality on various forms of firm performance. Bhagat and Bolton (2008) find a significant positive relationship between the dual role of the CEO and performance. Pathan (2009), in support of the argument, suggests that CEO duality may reduce any potential bank risk. Similarly, Naushad and Malik (2015) conclude that it is likely to improve bank performance. However, Wang et al. (2012), Carter et al. (2003) and Isik and Hassan (2002) report a negative impact of CEO duality on various aspects of performance. The disparities in the findings show that the relationship between CEO duality and bank performance is inconclusive and, therefore, evidence from different banking environment is required for contextual policy making.

Board diligence is another proxy of CG measures the number of the board meeting held within a year. The board meeting is considered beneficial to shareholders. This is because as the board regularly holds meetings, they are well informed about the performance of the company, which enables them to direct issues appropriately (Abbott, Parker, Peters, \& Raghunandan, 2003). Board expertise described as the qualification held by members of the board, particularly outside directors. It is usually measured by the percentage of directors with financial expertise (Aebi, Sabato, \& Schmid, 2012; Erkens, Hung, \& Matos, 2012). Banking has grown to become more complex and more opaque (Mehran et al., 2011), requiring industry-specific expertise (Haan \& Vlahu, 2016). Although outside directors (supervisory directors) possess knowledge from other sectors of the economy when they do not have sufficient knowledge of banking, they cannot effectively monitor the executive board (Haan \& Vlahu, 2016). Some studies have assessed the impact of board expertise on performance, with mixed results. Hau and Thum (2009), in their study of German banks, found that banks with boards having less financial expertise have higher losses. However, Aebi et al. (2012) found a negative relationship with performance measured as ROA. Interestingly, Erkens et al. (2012) found 
no significant relationship. Considering that when independent directors are well equipped with the right know-how, it will improve their monitoring of firm performance, making them able to take the right action.

The theory of agency emphasises the need for managerial ownership in driving better corporate governance and, consequently, improved performance in firms. For instance, the agency theory posits that through ownership of firms, the interests of managers could be aligned with the interest of shareholders by making managers to gradually become part of the owners. That is, if the directors share in the ownership of a bank, they would provide proper supervisory and monitory roles to ensure shareholder wealth maximisation.

Institutional ownership refers to shareholders of a company who are firms or corporate bodies rather than individuals. Institutional owners of firms are key in ensuring the overall effectiveness of governance mechanisms in firms, and monitoring of managerial behaviour in a way that minimises agency costs. The agency researchers suggest that the institutional owners or investors of firms result in more effective monitoring than individual shareholders, thereby resulting in better performance of firms with more institutional ownership.

\section{Capital structure (CS) and firm performance}

Empirical studies linking CS and bank performance provides mixed and contradictory results, and little attention given to developing economies, like Ghana. While most studies in the developed economies found a positive relationship between capital structure and firm performance (Berger \& Di Patti, 2006; Gill, Biger, \& Mathur, 2011; Margaritis \& Psillaki, 2010), similar studies in developing and emerging economies find otherwise (Majumdar \& Chhibber, 1999; Zeitun \& Gang Tian, 2007). They argued that the role of debt as a monitoring channel to improve firm performance is not considered in emerging markets. Thus, large cash flow from debt can lead managers to undertake discretionary behaviour or negatively affect firm performance. Berger and Bouwman (2013) examine the effect of capital on bank performance and how this effect was influenced by the various crisis in the US banking industry. The study concluded that capital structure helps small banks to increase their chances of survival, and there was a significant positive relationship between capital structure and the performance of the large and medium-sized banks in the US banking industry.

Nikoo (2015) found a positive and significant relationship between capital structure and bank performance by employing the data of 17 banks throughout 2009-2014. Hasan, Ahsan, Rahaman and Alam (2014) used data on 100 listed firms in Bangladesh throughout 2006-2009 and observed a significant positive association between the performance of a firm and capital structure. They used ROA, Earnings per Share (EPS) and net profit margin as proxies to measure the performance and short-term debt obligations to total asset (STD), long-term debt obligations to the total asset (LTDTA), and total debt obligations to total asset (TDTA) as the capital structure variables. The authors claimed, based on exponential generalised least squares approach, that their findings support the trade-off theory. "Salteh, Ghanavati, Khanqah, and Khosroshahi (2012) investigated the influence of capital structure decision on the profitability of 28 firms from the Tehran stock exchange. They, while considering the data for 2005-2009, observed positive impacts of capital structure variables, STDTA, LTDTA, TDTA, on the performance proxies by ROE and Tobin's Q". Arbabiyan and Safari (2009), using the data of 100 firms for 2001-2007, reported a significant positive link of STDTA and TDTA with ROE. However, the authors observed an inverse association of LTDTA with ROE. The main drawback of this study was that they used only a single variable, ROE, to measure the performance.

Some recent studies have found a non-linear relationship between capital structure and firm performance, that is, a capital structure can have both positive and negative effects on firm performance. Abor and Biekpe (2005), for instance, found a positive linear relationship between CS and performance of SMEs in the Ghanaian context. Specifically, at a low level, debt can increase firm performance through the tax shield, reducing agency costs of equity or informing a better prospect. However, when leverage is sufficiently high, an increase of debt ratio can decrease firm performance, because the benefits of debt are overcome by the costs of debt, including financial distress and agency costs of debt (Jensen, 1986; Kraus \& Litzenberger, 1973).

\section{Interaction between Governance Structure and Capital Structure}

Extensive literature review revealed few studies conducted on capital structure and corporate governance and their interaction on firm performance. The results of these studies have shown mixed results. For instance, Rehman, Rehman and Raoof (2010) investigated the relationship between governance structure and capital structure, using 19 firms in Pakistan from 2005-2006 and found a positive relationship. The study also concluded that firm performance is improved through the interaction of governance and capital structure. A similar positive relation was reported by Rajendran (2012) in his study of Sri-Lanka manufacturing firms. In the African context, Chomba (2013) focused on the effect of corporate governance structure on capital structure and ignored the fact that capital structure may also influence the firm performance in Kenya. Contradictory findings are reported by Saad (2010), who studied 126 Malaysian publicly listed companies, and the results showed a negative relationship. Due to such mixed findings, 
there is the need for a Ghana specific study to establish which school of thought is supported by the Ghanaian phenomenon.

\section{The Ghanaian banking industry}

Modern banking began in Ghana in the late nineteenth century when the Post Office Savings Bank (POSB) commenced operations in 1888. The POSB conducted its operations, using the facilities of the various post offices dotted around the country. However, full banking activities started in the then Cape Coast in 1896 when the British Bank for West Africa (BBWA), now the Standard Charted Bank (SCB), opened a branch in Accra to deliver primary banking services. The focus of the bank then was the provision of trade finance mainly to expatriates. The SCB successfully maintained government accounts and introduced cheques for the settlement of Government accounts. In 1917, that is, two decades after the founding of the SCB, Barclays Bank DCO (Dominion Colonial Overseas), now Barclays Bank Ghana (BBG) Limited, was established. These two banks were foreign subsidiaries of Banks registered in the United Kingdom (UK) and mainly provided finance to facilitate trade between Ghana and the UK. In 1921, the West African Currency Board (WACB) was established by the British administration to be responsible for issuing currency of various denominations for colonies such as the then Gold Coast, Gambia, Nigeria and Sierra Leone. The farmers' Co-operatives, in collaboration with the colonial government, launched the Co-operative Bank in 1935. Apart from the normal banking services, the Co-operative Bank devoted attention to strengthening cooperatives and extended financial assistance to the cocoa sector to boost cocoa marketing in the country. Together, these two expatriate banks exclusively provided banking services in the Gold Coast from the 1920s to the early 1950s. They operated commercial banks, provided trade finance to commercial firms, and were used by the colonial government to pay salaries.

In 1953, based on the recommendation of Sir Cecil Trevor, a national, Bank of Gold Coast (BGC) was established with the mandate to serve the local private sector; keep government accounts as well as leading the flotation of government bonds. In the events leading up to independence, the BGC was split into two, one arm became the Central Bank (Bank of Ghana), and the other the Ghana Commercial Bank (GCB). Thus, the Bank of Ghana (BoG hereafter) was established by Bank of Ghana Ordinance (No. 34) of 1957 two days before independence, and charged to take over currency issue and other central banking functions from the WACB. In the same year, July 1957 the BoG issued for the first time the cedi to replace the West Africa currency notes. The newly established Central Bank established branches in the towns it operated in and later extended coverage to the Ashanti and the Northern Regions to hold its own against the expatriate banks. Upon the attainment of independence, the new banks were established to provide large volumes of capital to support the private sector. Banks incorporated between 1957 and 1980 are the National Investment Bank (1964); the Agricultural Development Bank (1965); the Bank for Housing and Construction (1972); the Merchant Bank Ghana Limited (1972); The National Savings and Credit Bank (1975); Social Security Bank (1977); the Bank of Credit and Commerce (1978). Within the period, the state steered the development of the banking sector through the establishment of state banks and intervening directly in the credit market in a bid to ameliorate cost and channel credit to priority sectors.

\section{Reformation of banking in Ghana}

The Ghanaian banking industry has undergone regulatory and structural changes since the mid-1980s (Alhassan \& Ohene-Asare, 2013). In 1983, as a remedy to the economic crisis the country was experiencing, the government of Ghana, under the assistance of the International Monetary Fund (IMF), introduced the Economic Recovery Programme (Ohene-Asare \& Asmild, 2012). This signalled an end to socialism and curbed the various effect on trade and finance, arising from legal restriction. The law also encouraged private investment with the intent of promoting growth and development. The Banking Law also created an environment to promote local institutions to file for licenses to operate as banks (Alhassan \& Ohene-Asare, 2013). In particular, the authorisation for the establishment of private banks, following the passage of the Banking Act of 1989, led to the entrance of private banks, such as CAL Merchant Bank (1990); Ecobank Ghana Limited (1990); Meridian Bank (1991); Trust Bank (1995); Metropolitan and Allied Bank (1995); First Atlantic Merchant Bank; Prudential Bank (1996); and International Commercial Bank (1996). Since 2000, new banks have entered the banking scene. To incorporate the diverging trend in the banking industry globally, the Ghana banking sector was revamped in 2004 through the introduction of the Banking Act 2004 (Act 673) (Aboagye, Akoena, Antwi-Asare \& Gockel, 2008).

The banking industry has since received several notable developments. Mention can be made of the increase in the minimum capital requirement of universal banks, which gave banks with 70 billion cedis in the capital the authority to undertake all the banking activities, unlike previously where they could only undertake the activities which they were specifically licensed to perform (Bokpin, 2013a). Second is the enactment of the Banking Act 2004 (Act 673) under which banks were required to increase the minimum capital requirement to US\$ 8 million, which was later increased to US\$ 30 million and US\$ 60 million in 2012 and 2013, respectively (Alhassan, 2015). Another development was the change of currency from the cedi to the Ghana cedi in July 2007 (BOG, 2007). Other significant 
legislation enacted to drive banking activities were "Foreign Exchange Act 2006 (Act 723), Whistle Blowers Act 2006 (Act 720), Credit Reporting Act 2007 (Act 726), Banking (Amendment) Act 2007 (Act 738), Borrowers and Lenders Act 2008 (Act 773), Non-Banking Financial Institutions Act 2008 (Act 774), Home Mortgage Finance Act 2008 (Act 770), Anti-money Laundering Act 2008 (Act 749)". During these development stages, there were significant mergers and acquisitions of banks, resulting principally from the increases in the minimum capital requirement (Bokpin, 2013a; Isshaq \& Bokpin, 2012). As of 2015, the banking industry of Ghana consisted of 30 universal banks (an increase from 18 in 2003, BoG, 2015). Based on majority ownership (of 60 per cent of ordinary shares), the banks in Ghana can be grouped into 14 locally-owned and 16 foreign-owned. Out of the 30 banks, 7 are listed on the Ghana Stock Exchange. Out of the listed banks, 4 are locally-owned, while 3 are foreign-owned. Out of the 23 non-listed banks, 10 are locally-owned while 13 are foreign-owned.

The reforms in banking also resulted in bringing rural banking, which was neglected. Rural residents had to travel long distances to receive payments, such as salaries and pensions, transfer money and cash cheques for their farm produce. They mainly relied on high interest charging moneylenders and traders for credit. Limiting factors, such as collateral requirements, the need to have an account, and the seasonal high-risk nature of rural occupations (predominantly agriculture), precluded the rural folks from gaining access to formal credit. The concept of rural banking was, therefore, introduced in 1976 to provide banking services to the rural population and address the challenges associated with the accessibility of banking services. The first rural bank, Agona Nyankrom Rural Bank, was established in a farming community in the Central Region. In less than a decade after the establishment of the first Rural Bank, the number of Rural and Community Banks (RCBs) was 106 by 1984. In 1981, the existing Rural Banks collaborated to form an Association of Rural Banks (ARB) called the ARB APEX Bank. The aim was to advance the common course of RCBs. It provided a platform for networking and represented RCBs on key matters at the central bank. By 2010, the number of RCBs reached 135. There was a total of 142 Rural and Community Banks (RCBs) as the end of 2015.

Over the past decade, some reforms have been adopted by Ghana to build, upgrade and modernise the financial system. The principal is the drive towards computerising banking activities, particularly with the influx of automated teller machines (ATMs). For example, the number of ATMs across the country equals 618 as of 2011. "The computerisation process also includes the introduction of mobile banking, SMS banking and internet banking products. Following the introduction of ATMs, the Payment Systems Act 2003 (Act 662) was enacted to regulate the operation and supervision of electronic funds transfer, clearing and settlement systems. This led to the development of a national payment and settlement system called the E-zwich payment system. The E-zwich smart card provides holders and merchants with a nationwide and convenient means of transacting business by reducing the paper-based transactions. Apart from E-zwich, some of the payments and settlement reforms that have been implemented include Real Time Gross Settlement System (RTGSS), Central Security Depository (CSD), Automated Clearing House (ACH), Cheque Codeline Clearing (CCC), and the Ghana Interbank Payments and Settlement System (GHIPSS)"(BOG, 2015).

Some of the reforms geared towards strengthening the supervisory and regulatory framework of the financial sector include Risk-Based Supervision (RBS), Electronic Financial Analysis and Surveillance System (eFASS), etc. "In 2007, the enactment of the Credit Reporting Act 2007 (Act 726) led to the establishment of credit reference bureaus. The relevance of the bureaus is to bridge the information asymmetry in credit markets to ensure efficient allocation of resources to productive sectors in the economy. The intended role of the credit reference bureau is to support the credit risk management functions of banks" (BOG, 2015). The objectives of these reforms are to improve efficiency and ameliorate risk in the payment system, foster financial intermediation, widen the range of financial securities, and build infrastructure that aids interoperability

The financial infrastructure development has led to the introduction of new banking products and has boosted branchless and cashless banking. For example, the introduction of ATMs and E-Zwich, in particular, has made banking more accessible, reliable, convenient, fast, and efficient. The introduction of mobile banking has further enhanced branchless banking. Some of the mobile banking services available include money transfer, airline ticket purchase, cash deposit, balance enquiry, cash withdrawal, credit top-up and payment of utility bills. One needs just a mobile phone, and not a bank account, to undertake mobile banking. This has improved financial inclusion by roping in a large number of the previously unbanked into the banking system. These broad range reforms have strengthened the financial infrastructure, leading to gains in financial deepening in the country. Measures of financial depth, such as deposit/GDP, M2/GDP, and credit to the private sector/GDP, have all improved (Bawumia, 2010). Though these reforms have modernised the national payment and securities payment systems and strengthened the legal and regulatory framework, more reforms on regulatory and supervisory oversight are needed to improve and sustain the gains in financial development in Ghana. 
Board diversity issues in Ghana

Unlike jurisdictions such as the US and the UK, Ghana does not have a single comprehensive corporate governance framework. Rather, as with the laws that govern financial reporting in Ghana, the rules that govern the relationship among a business' stakeholders can be found in bits and pieces in different regulatory instruments. However, unlike with financial reporting rules, there is no single overarching set of principles for corporate governance for companies in Ghana.

The Companies Code contains some corporate governance provisions that all companies are required to comply with. These include provisions on the number, appointment, duties, remuneration and removal of directors; shareholder meetings; rights of shareholders; and the appointment, duties, powers, remuneration and removal of auditors. Other corporate governance rules, such as the mix of executive and non-executive directors and the existence of board committees, are not covered by the Code. Provisions on these other corporate governance best practices can, however, be found in other laws. In addition to the Companies Code, listed companies are required to comply with corporate governance principles set out in the Securities Industry Law (1993), the Securities Industries (Amendment) Act 2000, the SEC Regulations (2003) and the GSE Listing Regulations. Companies within the banking, insurance, and minerals and mining industries also have to comply with additional corporate governance contained in the laws regulating these industries. These laws include the Insurance Law (1989), the Banking Law (1989) and the Banking Act (2004).

Voluntary corporate governance codes in Ghana include the Ghana Manual on Corporate Governance issued by the Private Enterprises Foundation (PEF) and the Institute of Directors (IOD); and the SEC Guidelines on Best Corporate Governance Practices. The SEC guidelines are principally based on OECD principles. These voluntary codes, however, have little recognition in Ghana and are mostly not adhered to. The lack of adherence to these voluntary corporate governance codes is hardly surprising given that even statutory laws in Ghana generally suffer from weaknesses in compliance.

As noted by the World Bank (2005), several key aspects of good corporate governance practices are observable in Ghana-protection of basic shareholder rights, basic AGM rules, the equitable treatment of shareholders in the law, and timely disclosures in the annual reports. There is, however, lack of a coherent and comprehensive regulatory framework for corporate governance practices. This has resulted in the following significant weaknesses in corporate governance practices in Ghana - no rules on board diversity, poor enforcement, lack of certain key disclosures, inconsistencies in the provisions relating to mergers in the Companies Code and the SEC regulations, single-tier boards and limited audit committee effectiveness (World Bank, 2005). Consequently, as with the regulatory framework for financial reporting, there is a need for comprehensive corporate governance rules in Ghana to address the weak level of corporate governance. The ability of the regulators to enforce compliance must also be enhanced to ensure a more effective adherence to the existing provisions of corporate governance.

This section explained the governance and capital structure theories and reviewed empirical literature relevant to the study. The literature revealed a significant relationship between governance structure and bank performance in both developed and developing economies. The bank financing decision is also revealed to influence bank performance and the agency theory is in consonance of this finding. Most of the studies reviewed are centred in developed economies with scant attention in developing countries. Notwithstanding these studies, the interaction effect of governance structure and capital structure on bank performance still stands as a gap in the literature, which is closed with the current study. The study investigates the effect of governance structure on bank performance, capital structure on bank performance and the interaction effect of governance structure and capital structure on the performance of the banks in the Ghanaian context.

\section{Methodology}

Data Source and Description

Data for the study were derived from the Bank of Ghana covering various variables for the period from 2003 to 2015 for all the universal banks in Ghana. The data is a panel in nature since it involves variables being studied across firms over a period. The use of secondary data source is deemed more appropriate for this research in that, apart from its relatively easy access and preciseness, it is also devoid of subjectivity associated with other modes of data collection, such as interviews and questionnaires. Again, the regulatory framework governing the preparation of company annual reports helps ensure that the annual report is a reliable and attested public document (Ghazali, 2010). Twenty-nine banks out of thirty-four (34) were studied over thirteen years, giving 377 observations, which represent 85 per cent of banks in Ghana as of 2015. 


\section{Model Specification}

Based on the relationships, as discussed in the literature review section, we specify the following functional form relationship between the indicators for bank performance and the regressors as:

$$
R O E=f(L E V, S I Z E, A U D T Y P, L R)
$$

When we introduce the interaction terms for governance structure and capital structure on bank performance, the reduced form of equation (1) is:

$$
R O E_{i t}=\alpha+\beta_{1}\left(B S I Z E_{i t}+D I V_{i t}+B D \exp _{i t}\right)^{*} \beta_{2}\left(L E V_{i t}\right)+\beta_{3} S I Z E_{i t}+\beta_{4} A U D T Y P_{i t}+\beta_{5} L R_{i t}+\varepsilon_{i t}
$$

where,

$\mathrm{ROE}$ is the return on equity, the measure for bank performance (we also used return on asset as an alternative measure of bank performance);

BSIZE is board size

DIV is board diversity

BDexp is board expertise

AUDTYP is a dummy for audit committee

SIZE is the size of a bank and

LR is the liquidity risk of a bank

Table 1 describes how the variables in this paper are measured.

Table 1: Variables used in the measure of firm performance, capital structure and governance structure

\begin{tabular}{ll}
\hline Variables & Measure \\
\hline ROE & Earnings after interest and tax / Book value of equity \\
Capital structure (LEV) & Equity/(Book Value of Total Asset) \\
Board size (BSIZE) & Number of the board of directors \\
Board gender diversity (DIV) & The proportion of female directors on the Board \\
Audit Committee (AUDTYP) & Dummy Variables of 1 is bank have an audit committee and 0 \\
& otherwise \\
Board Expertise (BDexp) & The proportion of directors with finance-related qualification \\
Size (SIZE) & Natural log of total assets \\
Risk (LR) & A measure of liquidity risk defined as the cash ratio \\
\hline
\end{tabular}

Source: Authors

Data analysis

To explore the data and to assist in the identification of potential data errors, descriptive statistics were utilised to summarise and describe the firms' variables by industry and in total. Correlation analysis for variables was used to discover the links between governance structure, capital structure and firm performance of the banks. The study then used pooled ordinary least square (OLS), fixed effect (FE) and random effect (RE) estimation methods to investigate the degree and direction of the variables' relationships, after controlling for firm characteristics. The use of the RE model helps to control unobserved effects as well as heteroskedasticity. However, the method does not remove endogeneity issues between the regressors and the innovation term, which can lead to biased and inconsistent estimators. This is usually caused by the inability to ascertain if a simultaneous reverse relation link exists between capital structure and firm performance (i.e., bank performance also affects capital structure decisions). Besides, the capital structure can be considered simply an indicator of unobserved features that influence performance. To address the issue of endogeneity, the paper further used generalized method of moment (GMM) to examine the persistent relationship among the variables. In the GMM estimation, the first-lags of the independent variables were used as instruments, since they are correlated with the independent variables, but are uncorrelated with the innovation term.

\section{Results and Discussion}

A discussion of the data used, and the interpretation of the results is presented in this section. Also, variables used as the proxy for corporate governance and capital structure as well as performance is discussed. Consequently, the results are presented logically with the intent of achieving the objectives of this research. Also, a discussion of the results is provided as a means of approving or disproving the various hypotheses and arguments raised. 


\section{Summary of Statistics Variables}

Table 2 provides the descriptive statistics of the variables adopted for the study for the period 2003 to 2015. From Table 2, the means, standard deviation (Std. Dev.), minimum (Min) and maximum (Max) values of the variables are presented. The table shows that commercial banks in Ghana have an average of 3 per cent return on equity (ROE). From the table, the average board size is 6 members. Considering the presence of an audit committee of commercial banks, the study shows 56.4 per cent of banks in Ghana have audit committees, while 40.4 per cent are locally owned. The capital structure on banks is dominantly made of debt due to the deposit mobilisation functions of Banks. On average, the equity contribution as a percentage of the total asset base is 15.6 per cent.

Table 2: Summary Statistics (2003-2015)

\begin{tabular}{lccccc}
\hline \multicolumn{1}{c}{ Variables } & Mean & Median & Max & Min & Std. Dev. \\
\hline SIZE & 19.151 & 19.683 & 22.608 & 0 & 3.135 \\
ROE & 0.247 & 0.251 & 2.022 & $(4.399)$ & 0.398 \\
TLEV & 0.156 & 0.126 & 1.411 & 0 & 0.129 \\
BSIZE & 6.165 & 8.000 & 15.000 & 0 & 4.435 \\
BGDIV & 0.090 & 0.083 & 0.500 & 0 & 0.107 \\
BEXP & - & - & 1.000 & 0 & 0.296 \\
AUDTYP & 0.564 & 1.000 & 1.000 & 0 & 0.497 \\
\hline
\end{tabular}

Note: ROE $=$ Return on Equity, BSIZE $=$ Board Size, BGDIV $=$ Board Diversity, BEXP $=$ Board Expertise, AUDTYP $=$ Audit committee present, Size $=$ Natural $\log$ of total asset, $L R=$ Banks liquidity risk, TLEV = Capital Structure measure with ratio of equity to book value of asset.

Source: Authors (2020) estimated from Bank of Ghana Data (2015).

\section{Correlation Analysis}

Correlation analysis is used to measure the strength of a linear association between two variables. The Pearson correlation coefficient, denoted as $\mathrm{r}$, can take values ranging from -1 to +1 . According to Cooper and Schindler (2003), a value of -1 indicates a perfect negative correlation, which implies that an increase in one variable is followed by a proportionate decrease in the other variable, while a value less than zero indicates a negative association between the two variables, implying that as the value of one variable increases, the value of the other variable decreases and vice versa. A value of zero indicates no association exists between the two variables. Any value of $r$ greater than 0 indicates a positive association between the variables, implying that as the value of one variable increases, the value of the other variable equally increases.

A value of the correlation coefficient of 1 designates perfect positive correlation, which implies that an increase/decrease in one variable is followed by a proportionate increase/decrease in the other variable. The value of the Pearson correlation Coefficient will be closer to either +1 or -1 , the stronger the association between the two variables. Sekaran (2006) states that Pearson's correlation is used if the variables of the study are measured, using either interval or ratio scales. In this study, the correlation results are reported at a significance level of $0.1,0.05$ and 0.01 .

The correlation coefficients between variables used in the regression models are presented in Table 3 and it shows that there is a statistically significant positive correlation between Board Size and Firm performance $(r=0.131$, $\mathrm{p}<.01$ ), meaning that the returns on equity of bank increases as board size increases. There was a positive correlation between Board Size and return on asset $(r=0.09, p<0.1)$. Equity to book value of the total asset used as a proxy for the capital structure was found to be negatively related to performance proxied with return on asset (ROE) because coefficients of pairwise correlation among the variables are negative and significant at the $5 \%$ level. Specifically, the correlation coefficients presenting the link of TLEV with ROE is -0.223 . This denotes that an increase of $1 \%$ in equity to total asset ratio will lead to a decrease of approximately $22 \%$ in ROE, holding all other variables constant.

Table 3: Correlation Analysis

\section{Correlation}

\begin{tabular}{|c|c|c|c|c|c|c|c|c|}
\hline Probability & AUDTYP & BEXP & BGDIV & BSIZE & LR & ROE & SIZE & TLEV \\
\hline AUDTYP & 1 & & & & & & & \\
\hline \multirow[t]{2}{*}{ BEXP } & 0.405 & 1 & & & & & & \\
\hline & $0.000 * * *$ & & & & & & & \\
\hline BGDIV & 0.352 & 0.393 & 1 & & & & & \\
\hline
\end{tabular}




\begin{tabular}{c|rrrrrrrr} 
& $0.000^{* * *}$ & $0.000^{* * *}$ & & & & & & \\
BSIZE & 0.422 & 0.374 & 0.439 & 1 & & & & \\
& $0.000^{* * *}$ & $0.000^{* * *}$ & $0.000^{* * *}$ & & & & \\
LR & -0.069 & -0.037 & -0.157 & 0.015 & 1 & & \\
& 0.230 & 0.520 & $0.006 * * *$ & 0.791 & & & \\
ROE & 0.110 & 0.253 & 0.188 & 0.131 & -0.131 & 1 & \\
& $0.056^{* *}$ & $0.000^{* * *}$ & $0.001 * * *$ & $0.022^{* *}$ & $0.022^{* *}$ & & \\
SIZE & 0.413 & 0.420 & 0.548 & 0.396 & -0.179 & 0.289 & 1 \\
& $0.000^{* * *}$ & $0.000^{* * *}$ & $0.000^{* * *}$ & $0.000^{* * *}$ & $0.002 * * *$ & $0.000 * * *$ & & \\
TLEV & 0.090 & -0.042 & -0.041 & -0.037 & 0.072 & -0.223 & 0.038 & 1 \\
& 0.119 & 0.469 & 0.481 & 0.525 & 0.209 & $0.000 * * *$ & 0.509 & \\
\hline
\end{tabular}

Note: ROE $=$ Return on Equity, BSIZE $=$ Board Size, BGDIV $=$ Board Diversity, BEXP $=$ Board Expertise, AUDTYP $=$ Audit committee present, Size $=$ Natural $\log$ of total asset, $L R=$ Banks liquidity risk, TLEV $=$ Capital Structure measure with ratio of equity to book value of asset. **significant at 0.05 and $* * *$ at 0.01 .

Source: Authors (2020) estimated from Bank of Ghana Data (2015).

\section{Effect of Capital Structure on Bank Performance}

Table 4 reports the results of examining the relationships between capital structure (CS) and firm performance, which were estimated by pooled OLS estimators. The table also shows the outcomes of FE and RE models. Both models' results provide that the coefficients of leverage ratio are negative, but differ slightly in the significance levels. To select the appropriate model between FE and RE, the Hausman test was performed. The results of the chi-square statistic are 0.66 , meaning it is not statistically significant at $1 \%$; therefore, we reject the null hypothesis and conclude that the models favour Random Effect. Hence, the RE estimator was used to investigate the effect of equity finance on the banks' performance. The results of the empirical model, using the RE, confirm that the relationship between capital structure and bank performance is negative. In general, it reveals a negative relationship between capital structure and firm performance, because most estimated coefficients of equity ratio measured by the book value of the asset are negative and statistically significant at the $1 \%$. On average, a $1 \%$ increase in equity will lead to a decrease of $0.48 \%$ in ROE, holding all other variables constant. This means that just by increases the capitalisation of the banks does not mean that the performance of the banks would increase.

Table 4: Effect of Capital Structure on Bank Performance

\begin{tabular}{lcrr}
\hline Variable & Dependent Variable (ROA) & & \\
& OLS & FE \\
C & & & \\
& 0.186 & 0.303 & 0.261 \\
TLEV & $(0.20)$ & $(0.044)$ & $*(0.074)$ \\
& -0.464 & -0.470 & -0.475 \\
AUDTYP & $* * *(0.004)$ & $* *(0.017)$ & $* * *(0.005)$ \\
& -0.003 & -0.062 & -0.032 \\
LR & $(0.950)$ & $(0.313)$ & $(0.542)$ \\
& -0.220 & -0.220 & -0.224 \\
SIZE & $* * *(0.002)$ & $* * *(0.004)$ & $* * *(0.002)$ \\
& 0.010 & 0.006 & 0.008 \\
R-squared & $(0.155)$ & $(0.398)$ & $(0.294)$ \\
Adjusted R-squared & 0.064 & 0.247 & 0.057 \\
Observation & 0.052 & 0.158 & 0.045 \\
F-statistic & 301 & 301 & 301 \\
Prob(F-statistic) & 5.132 & 2.767 & 2.767 \\
\hline
\end{tabular}


Note: ROE $=$ Return on Equity, TLEV = Capital structure measure with equity to book value of total asset, AUDTYP $=$ Audit committee present, Size $=$ Natural $\log$ of total asset, $\mathrm{LR}=$ Banks liquidity risk $*, * *, * * *=$ significance level at $0.1,0.05$ and 0.01 respectively.

Source: Authors (2020) estimated from Bank of Ghana Data (2015).

To strengthen the research outcomes, the two-step system GMM with the adjusted standard error was applied to cope with the endogenous problem. The outcomes of the system GMM are reported in Table 5. It confirms the negative relationship between capital structure and firm performance. This negative relation is mostly statistically significant at the $1 \%$ level. A negative relationship between capital structure and firm performance is reported by all models. The consistency of the capital ratio sign under the different methods applied illustrates the robustness of the findings. This could be explained by Harris and Raviv (1991), who suggested that underestimating bankruptcy costs of liquidation or re-organisation may lead firms to have more debt than the appropriate level; therefore, a high debt ratio would decrease firm performance. Besides, large cash flow from debt can lead managers to undertake discretionary behaviour that can negatively affect firm performance.

Table 5: GMM Regression of Capital Structure and Bank Performance

\begin{tabular}{lrrrr}
\hline Variable & Coefficient & Std. Error & t-Statistic & Prob. \\
\hline C & 0.261 & 0.146 & 1.790 & 0.074 \\
TLEV & -0.475 & 0.169 & -2.818 & 0.005 \\
AUDTYP & -0.032 & 0.052 & -0.611 & 0.542 \\
LR & -0.224 & 0.072 & -3.124 & 0.002 \\
SIZE & 0.008 & 0.007 & 1.052 & 0.294 \\
\hline R-squared & 0.057 & Mean dependent var & & 0.140 \\
Adjusted R-squared & 0.045 & S.D. dependent var & & 0.357 \\
S.E. of regression & 0.350 & Sum squared resid & & 36.437 \\
Durbin-Watson stat & 1.616 & J-statistic & & 0.000 \\
\hline
\end{tabular}

Note: $\mathrm{ROE}=$ Return on Equity, TLEV = Capital structure measure with equity to book value of total asset, AUDTYP $=$ Audit committee present, $\mathrm{Size}=$ Natural $\log$ of total asset, $\mathrm{LR}=$ Banks liquidity risk $*, * *, * * *=$ significance level at $0.1,0.05$ and 0.01 respectively

Source: Authors (2020) estimated from Bank of Ghana Data (2015).

Effect of governance structure on bank performance

The analysis in Table 6 shows that the F statistic is 2.87 and is greater than the critical value at one per cent level of significance. Therefore, the variables which are used for governance structure are jointly significant in explaining the variations in return on equity. The overall $\mathrm{R}^{2}$ is 26.7 per cent, indicating that the variables considered in the model account for about 27 per cent change in the dependent variables, while about 73 per cent change may be as a result of other variables not addressed by this model. The second column in Table 6 presents the results for the RE estimation. The coefficient of determinations, R-square, shows the within and between values of 0.076 percentage point. A comparison of the post-estimation diagnostics between the fixed and random effects specification reveals that the conclusions are comparable. The overall explanatory powers of the specifications are significantly different. The fixed effect specification explains an overall explanation power of 27 per cent point, while the random effects model has an overall explanation power of 7.6 per cent. However, the consistency in post-estimation diagnostics does not eliminate the need to discriminate between the models.

Table 6) shows the Hausman's test statistic that has a chi statistic of 8.34 and a corresponding p-value of 0.21 . This implies that the null hypothesis that the regressors and individual heterogeneity are strictly exogenous cannot be rejected at one per cent level of significance. Thus, the RE specification is preferred to the FE specification. Therefore, in analysing the effect of governance structure on bank performance proxied with return on equity, fixed effects models were interpreted.

Table 6: Regression Result on the Effect of Bank Governance on Bank Performance

\begin{tabular}{llll}
\hline Variable & FE & RE & GMM \\
\hline C & 0.196 & 0.188 & 0.154 \\
& 0.146 & 0.142 & 0.142 \\
BSIZE & $0.030^{* * *}$ & $0.021^{* * *}$ & $0.014^{* *}$ \\
& 0.009 & 0.007 & 0.007
\end{tabular}




\begin{tabular}{|c|c|c|c|}
\hline \multirow[t]{2}{*}{ BGDIV } & -0.351 & -0.071 & 0.178 \\
\hline & 0.303 & 0.252 & 0.229 \\
\hline \multirow[t]{2}{*}{ BEXP } & 0.173 & $0.193 * *$ & $0.193 * *$ \\
\hline & 0.134 & 0.094 & 0.078 \\
\hline \multirow[t]{2}{*}{ AUDTYP } & $-0.191 * *$ & $-0.151 * *$ & $-0.118 * *$ \\
\hline & 0.075 & 0.061 & 0.055 \\
\hline \multirow{2}{*}{ LR } & $-0.201 * * *$ & $-0.219 * * *$ & $-0.221 * * *$ \\
\hline & 0.074 & 0.071 & 0.072 \\
\hline \multirow[t]{2}{*}{ SIZE } & 0.001 & 0.002 & 0.004 \\
\hline & 0.008 & 0.007 & 0.007 \\
\hline R-squared & 0.267 & 0.076 & 0.089 \\
\hline Adjusted R-squared & 0.174 & 0.058 & 0.071 \\
\hline Sum squared resid & 32.439 & & \\
\hline Log likelihood & -91.430 & 0.349 & 0.369 \\
\hline F-statistic & 2.870 & 4.080 & 1.446 \\
\hline Prob(F-statistic) & 0.000 & 0.001 & 0.000 \\
\hline Hausman's test (p-value in parenthesis) & $8.34(0.210)$ & & \\
\hline \multicolumn{4}{|c|}{$\begin{array}{l}\text { Note: } \mathrm{ROE}=\text { Return on Equity, BSIZE }=\text { Board Size, LR=Liquidity Risk, BGDIV = Board Diversity, BEXP = } \\
\text { Board Expertise, AUDTYP = Audit committee present, Size = Natural log of total asset, } * * *, * * *= \\
\text { significance level at } 10 \%, 5 \% \text { and } 1 \% \text { respectively. } \\
\text { Source: Authors (2020) estimated from Bank of Ghana Data (2015). }\end{array}$} \\
\hline
\end{tabular}

From Table 6, board size has a significant and positive impact on the bank's return on equity. The implication is that the more people Ghanaian banks put on their board, the more returns they are expected to earn. The findings support the proposition of the resource dependency theory which suggest that a larger board size enables a firm to derive the essential resources for effective and efficient operations (Bilimoria \& Wheeler, 2000). A likely reason for the findings is that larger board size draws more resources, expertise and may also provide better decisions geared at improving cost, and hence increasing earnings. The findings are consistent with that of Huang, Lai, McNamara and Wang (2011), who found a positive impact of board size on the performance of US insurers. However, the results contradict the proposition of the agency theory (Jenseng et al., 1976), which indicates that smaller board size increases efficiency. Previous studies have reported board size to impact significantly, but negatively on performance. The findings of Wang et al. (2007) explained that board size negatively affects performance, because as the number of board directors increases, the cost incurred from conflicts and interactions increases correspondingly which, in turn, reduces banks earnings. Some studies also found no significant impact of board size of corporate financial performance (Yeh, Wang, \& Chai, 2010). The differences in the findings suggest that the issue of the nexus between board size and bank performance should not be viewed without recourse to banking systems' idiosyncrasies.

Board expertise also has a positive significant impact on the return on equity of banks in Ghana. Thus, the coefficients indicate that all things being equal, when the proportion of the board with finance-related expertise increases, banks performance will increase by $19.3 \%$. The findings imply that when more of the directors have skills or qualification that are finance-related, their experience and expertise help to increase the earnings of their banks (Minton, Taillard, \& Williamson, 2010). The study also reports a negative but insignificant impact of board diversity on return on equity of banks in Ghana. Thus, all else being equal, an increase in the proportion of board diversity (female directors on the board) reduces the banks' performance in Ghana. The conclusion is contrary to the proposition from resource dependency theory that a diversified board makes available essential resources for corporate performance (David \& David, 2016). Although female presence is promoted in several countries, the empirical result indicates otherwise in practice. Nielsen and Huse (2010) proposed that the impact of female on the board is dependent on the nature of the industry and the task to be performed.

The expertise of the audit committee of the board of directors significantly affects the performance of banks negatively. The estimated regression coefficient shows that increasing the proportion of directors with expertise in accounting and finance had led to an average reduction in returns on equity of banks by 15.2 per cent, ceteris paribus. The negative link between audit committee expertise and the performance of banks in Ghana is at variance with the postulations of the agency theory and the resource dependency theory. Also, previous studies suggest that the presence of audit committees and the size and independence of the audit committee of banks enhance performance (Black \& Kim, 2012; Hsu \& Petchsakulwong, 2010; Huang, Lai, McNamara, \& Wang, 2011; Wang et al., 2012; Wei, 2007; Spira \& Bender, 2004). Consequently, this result is consistent with studies in the non-banking industry, which suggest that the expertise of the audit committee sometimes impedes financial and market performance (Aldamen, Duncan, Kelly, McNamara, \& Nagel, 2012; Chan \& Li, 2008; Hsu \& Petchsakulwong, 2010).

The interaction effect of capital structure and governance structure on bank performance 
From Table 8 , the interaction between leverage and board diversity is statistically significant. This implies that interaction of board diversity and leverage enhance positively bank performance proxied with Return on Equity (ROE). It is also imperative to state that, when the model was run in Table 8, board diversity was not having a statistically significant effect on bank performance but, when interacted with leverage in Table 8 , the relationship is statistically significant. Concerning the sensitivity of the relationship, the interaction of board diversity and leverage's impact of bank performance is very sensitive. This is evidenced by a positive coefficient of 3.212. Bank performance is also statistically influenced by the interaction of board size and leverage (TLEVBS), showing the coefficient of 0.084 significant at 5 per cent level of significance. However, an interaction of board expertise and leverage is not statistically significant.

Table 8: Interaction Effect of Capital Structure and Governance Structure on Bank Performance

\begin{tabular}{|c|c|c|c|}
\hline Variable & FE & $\mathbf{R E}$ & GMM \\
\hline $\mathrm{C}$ & $\begin{array}{l}0.358^{* *} \\
(0.155)\end{array}$ & $\begin{array}{l}0.378^{* *} \\
(0.157)\end{array}$ & $\begin{array}{l}0.279^{*} \\
(0.152)\end{array}$ \\
\hline BEXP & $\begin{array}{l}0.158 \\
(0.132)\end{array}$ & $\begin{array}{l}0.134 \\
(0.133)\end{array}$ & $\begin{array}{l}0.104 \\
(0.229)\end{array}$ \\
\hline BGDIV & $\begin{array}{l}-0.782 * * \\
(0.383)\end{array}$ & $\begin{array}{l}-0.270 \\
(0.300)\end{array}$ & $\begin{array}{l}-0.337 \\
(0.301)\end{array}$ \\
\hline BSIZE & $\begin{array}{l}0.029 * * * \\
(0.009)\end{array}$ & $\begin{array}{l}0.015 \\
(0.011)\end{array}$ & $\begin{array}{l}0.030 * * * \\
(0.009)\end{array}$ \\
\hline SIZE & $\begin{array}{l}0.001 \\
(0.008)\end{array}$ & $\begin{array}{l}0.002 \\
(0.008)\end{array}$ & $\begin{array}{l}0.002 \\
(0.008)\end{array}$ \\
\hline TLEV & $\begin{array}{l}-0.850 * * * \\
(0.280)\end{array}$ & $\begin{array}{l}-1.105^{* * *} \\
(0.373)\end{array}$ & $\begin{array}{l}-0.477 * * \\
(0.195)\end{array}$ \\
\hline TLEVBGDIV & $\begin{array}{l}3.212 * \\
(1.715)\end{array}$ & & \\
\hline TLEVBSIZE & & $\begin{array}{l}0.083 * * \\
(0.042)\end{array}$ & \\
\hline TLEVBXP & & & $\begin{array}{l}0.424 \\
(1.317)\end{array}$ \\
\hline LR & $\begin{array}{l}-0.242 * * * \\
(0.075)\end{array}$ & $\begin{array}{l}-0.234 * * \\
0.074\end{array}$ & $\begin{array}{l}-0.226^{* * *} \\
0.074\end{array}$ \\
\hline AUDTYP & $\begin{array}{l}-0.189^{* *} \\
(0.073) \\
\end{array}$ & $\begin{array}{l}-0.169^{* *} \\
(0.075)^{* *}\end{array}$ & $\begin{array}{l}-0.189^{* *} \\
(0.074)^{* *}\end{array}$ \\
\hline R-squared & 0.292 & 0.293 & 0.283 \\
\hline Adjusted R-squared & 0.196 & 0.198 & 0.186 \\
\hline S.E. of regression & 0.343 & 0.343 & 0.345 \\
\hline Durbin-Watson stat & 1.731 & 1.739 & 1.724 \\
\hline Instrument rank & 37 & 37 & 37 \\
\hline
\end{tabular}

Note: $\mathrm{ROE}=$ Return on Equity, BSIZE $=$ Board Size, LR=Liquidity Risk, BGDIV = Board Diversity, BEXP = Board Expertise, AUDTYP $=$ Audit committee present, Size $=$ Natural log of total asset, $*, * *, * * *=$ significance level at $10 \%, 5 \%$ and $1 \%$ respectively.

Source: Authors (2020) estimated from Bank of Ghana Data (2015).

\section{Conclusion}

The study concludes that governance structure impacts on bank performance significantly. Larger board size is found to improve banks' financial performance. The results of the study suggest that a diversified board does not necessarily affect bank performance in Ghana. However, the expertise level of the board of directors affects positively bank performance. This implies that the experience and technical skill of the board members is a key determinant of bank 
performance. The presence of an audit committee also affects the performance of the bank. However, this impact is negative. This implies that the return on equity of banks with audit committee is not as high as those without audit committee, which can be due to the fees paid to audit committee members, which increases agency cost and minimises shareholder wealth.

The study also concludes that capital structure is also a determinant of bank performance. The gearing position of banks drives their level of performance. This, however, depends on the capital structure composition. It also implies that, while the capital structure affects bank financial performance, the interaction of board size and capital structure does not boost higher bank performance. An increase in the board size does not lead to an increase in shareholders equity that can improve the liquidity position of the banks which in turns can lead to higher bank performance. Finally, governance structure and capital structure jointly predict bank financial performance. Commercial banks with a good governance structure and optimal capital structure perform well financially. The implication is that when the board of directors and bank officials make optimal decisions, the banks tend to perform better.

The findings of this study add to the existing body of knowledge on corporate governance, capital structure and bank financial performance. The major contribution of the study is that governance structure and capital structure predict bank financial performance and that the effectiveness of a bank's management can induce investors to invest equity-capital to induce the financial performance of the bank. In effect, the study suggests that good management induces equity capital to promote shareholder wealth maximisation in Ghanaian banks. The study assists bank management to appreciate the linkages between board activities, management function and bank financial performance. The findings in this study suggest that bank capitalisation cannot insulate the outcome of bad bank governance and, therefore, it is not enough for regulators to increase the capitalisation status of the banks without proper governance structure and quality managerial decisions. The fact that risk management does not intervene in the relationship between corporate governance and banks' financial performance could be an indicator that risk management committees of the board do not have a significant impact on corporate risk management.

Based on the findings, some suggestions can be made for future research. Further research could be conducted by introducing the effect of the related-party transaction, branch diffusion and employing structure on the governanceperformance nexus. This could further widen the scope of the current study. The focus of the current study was on universal banks in Ghana. A similar study can be replicated for other financial institutions, like insurance companies and microfinance institutions. 


\section{References}

Abbott, L. J., Parker, S., Peters, G. F., \& Raghunandan, K. (2003). The association between audit committee characteristics and audit fees. Auditing: A Journal of Practice \& Theory, 22(2), 17-32.

Abdullah, A.-M., \& Naser, K. (2015). Determinants of Capital Structure of Banking Sector in GCC: An Empirical Investigation. Asian Economic and Financial Review, 5(7), 959-972.

Abdullah, H., \& Valentine, B. (2009). Fundamental and ethics theories of corporate governance. Middle Eastern Finance and Economics, 4(4), 88-96.

Aboagye, Q. q. A., Akoena, S. k., Antwi-Asare, T. o., \& Gockel, A. f. (2008). Explaining the market power of Ghanaian banks. South African Journal of Economics, 76(4), 569-585. DOI: 10.1111/j.18136982.2008.00221.x

Abor, J., \& Biekpe, N. (2005). Does corporate governance affect the capital structure decisions of Ghanaian SMEs? Paper presented at the Biennial Conference of the Economic Society of South Africa, Durban, South Africa, September.

Abor, J., \& Biekpe, N. (2007). Corporate governance, ownership structure and performance of SMEs in Ghana: implications for financing opportunities. Corporate Governance: The international journal of business in society, 7(3), 288-300.

Abor, J., \& Fiador, V. (2013). Does corporate governance explain dividend policy in Sub-Saharan Africa? International Journal of Law and Management, 55(3), 201-225.

Adams, R. B., \& Ferreira, D. (2009). Women in the boardroom and their impact on governance and performance. Journal of Financial Economics, 94(2), 291-309. DOI: http://dx.doi.org/10.1016/j.jfineco.2008.10.007

Adams, R. B., \& Mehran, H. (2003). Is corporate governance different for bank holding companies? Available at SSRN 387561.

Adewale, M. T., \& Ajibola, O. B. (2013). Does capital structure enhance firm performance? Evidence from Nigeria. IUP Journal of Accounting Research \& Audit Practices, 12(4), 43.

Aebi, V., Sabato, G., \& Schmid, M. (2012). Risk management, corporate governance, and bank performance in the financial crisis. Journal of Banking \& Finance, 36(12), 3213-3226.

Afriyie, H. O., \& Akotey, J. O. (2012). Credit risk management and profitability of selected rural banks in Ghana. Ghana: Catholic University College of Ghana.

Afriyie, H. O., \& Akotey, J. O. (2013). credit risk management and profitability of rural banks in the Brong-Ahafa region of Ghana. European Journal of Business and Management, 5.

Agoraki, M.-E. K., Delis, M. D., \& Staikouras, P. K. (2010). The effect of board size and composition on bank efficiency. International Journal of Banking, Accounting and Finance, 2(4), 357-386.

Agoraki, M. E., Delis, M. D., \& Staikouras, P. (2009). The effect of board size and composition on banking efficiency. International Journal of Banking, Accounting and Finance, II(4), 357-386.

Akhigbe, A., McNulty, J. E., \& Stevenson, B. A. (2016). Does the form of ownership affect firm performance? Evidence from US bank profit efficiency before and during the financial crisis. The quarterly review of economics and finance.

Akhtar, M. F., Ali, K., \& Sadaqat, S. (2011). Factors influencing the profitability of Islamic banks of Pakistan. International Research Journal of Finance and Economics, 66, 125-132.

Al-Tamimi, H., Hussein, A., Miniaoui, H., \& Elkelish, W. W. (2015). Financial Risk and Islamic Banks' Performance in the Gulf Cooperation Council Countries.

Alchian, A. A., \& Demsetz, H. (1972). Production, information costs, and economic organization. The American economic review, 777-795.

Aldamen, H., Duncan, K., Kelly, S., McNamara, R., \& Nagel, S. (2012). Audit committee characteristics and firm performance during the global financial crisis. Accounting \& Finance, 52(4), 971-1000. DOI: http://dx.doi.org/10.1111/j.1467-629X.2011.00447.x

Alhassan, A. L. (2015). Explaining Bank Productivity in Ghana. Managerial and Decision Economics, n/a-n/a. DOI: $10.1002 / \mathrm{mde} .2748$

Alhassan, A. L., \& Ohene-Asare, K. (2013). HAS COMPETITION IMPACTED ON EFFICIENCY OF GHANAIAN BANKS? 10th African Finance Journal.

Alipour, M., Mohammadi, M. F. S., \& Derakhshan, H. (2015). Determinants of capital structure: an empirical study of firms in Iran. International Journal of Law and Management, 57(1), 53-83.

Amidu, M., \& Wolfe, S. (2013). Do bank competition and diversification lead to greater stability? Evidence from emerging markets. Review of Development Finance, 3(3), 152-166. DOI: http://dx.doi.org/10.1016/j.rdf.2013.08.002

Ansari, A., \& Bideskan, M. S. S. (2012). Determinants of capital structure. Society for Business Research Promotion, 2(2), 51-63. 
Anum Mohd Ghazali, N. (2010). Ownership structure, corporate governance and corporate performance in Malaysia. International Journal of Commerce and Management, 20(2), 109-119.

Aruwa, S., \& Musa, O. (2014). Risk components and the financial performance of deposit money in Nigeria. International Journal of Social Sciences and Entrepreneurship, 1(11), 1-8.

Baltagi, B. H., \& Griffin, J. M. (1983). Gasoline demand in the OECD: An application of pooling and testing procedures. European Economic Review, 22(2), 117-137. DOI: http://dx.doi.org/10.1016/0014$\underline{2921(83) 90077-6}$

Bawumia, M. (2010). Monetary policy and financial sector reform in Africa: Ghana's experience: publisher not identified.

Berger, A. N., \& Bouwman, C. H. (2013). How does capital affect bank performance during financial crises? Journal of financial economics, 109(1), 146-176.

Berger, A. N., \& Di Patti, E. B. (2006). Capital structure and firm performance: A new approach to testing agency theory and an application to the banking industry. Journal of Banking \& Finance, 30(4), 1065-1102.

Bhagat, S., \& Bolton, B. (2008). Corporate governance and firm performance. Journal of Corporate Finance, 14(3), 257-273.

Bilimoria, D., \& Wheeler, J. V. (2000). Women corporate directors: Current research and future directions. Women in management: Current research issues, 2(10), 138-163.

Black, B., \& Kim, W. (2012). The effect of board structure on firm value: A multiple identification strategies approach using Korean data. Journal of Financial Economics, 104(1), 203-226. DOI: http://dx.doi.org/10.1016/j.jfineco.2011.08.001

Blumberg, B. F., Cooper, D. R., \& Schindler, P. S. (2014). Business research methods: McGraw-hill education.

Bokpin, G. A. (2011). Ownership structure, corporate governance and dividend performance on the Ghana Stock Exchange. Journal of Applied Accounting Research, 12(1), 61-73.

Bokpin, G. A. (2013). Ownership structure, corporate governance and bank efficiency: an empirical analysis of panel data from the banking industry in Ghana. Corporate Governance, 13(3), 274-287.

Bokpin, G. A. (2013). Ownership structure, corporate governance and bank efficiency: an empirical analysis of panel data from the banking industry in Ghana. Corporate Governance: The international journal of business in society, 13(3), 274-287.

Bokpin, G. A., \& Arko, A. C. (2009). Ownership structure, corporate governance and capital structure decisions of firms: Empirical evidence from Ghana. Studies in Economics and Finance, 26(4), 246-256.

Bokpin, G. A., \& Isshaq, Z. (2009). Corporate governance, disclosure and foreign share ownership on the Ghana Stock Exchange. Managerial Auditing Journal, 24(7), 688-703.

Brailsford, T. J., Oliver, B. R., \& Pua, S. L. (2002). On the relation between ownership structure and capital structure. Accounting \& Finance, 42(1), 1-26.

Brounen, D., De Jong, A., \& Koedijk, K. (2006). Capital structure policies in Europe: Survey evidence. Journal of Banking \& Finance, 30(5), 1409-1442.

Byrne, M. M. (2001). Evaluating the findings of qualitative research. AORN Journal, 73(3), 703-706.

Callen, J. L., Klein, A., \& Tinkelman, D. (2003). Board composition, committees, and organizational efficiency: The case of non-profits. Non-Profit and Voluntary Sector Quarterly, 32(4), 493-520. DOI: http://dx.doi.org/10.1177/0899764003257462

Carter, D. A., D'Souza, F., Simkins, B. J., \& Simpson, W. G. (2010). The gender and ethnic diversity of US Boards and Board committees and firm financial performance. Corporate Governance: An International Review, 18(5), 396-414. DOI: http://dx.doi.org/10.1111/j.1467-8683.2010.00809.x

Carter, D. A., Simkins, B. J., \& Simpson, W. G. (2003). Corporate governance, board diversity, and firm value. Financial Review, 38(1), 33-53.

Casu, B., Ferrari, A., \& Zhao, T. (2013). Regulatory Reform and Productivity Change in Indian Banking. Review of Economics and Statistics, 95(3), 1066-1077. DOI: 10.1162/REST_a_00298

Céspedes, J., González, M., \& Molina, C. A. (2010). Ownership and capital structure in Latin America. Journal of Business Research, 63(3), 248-254.

Chan, K. C., \& Li, J. (2008). Audit committee and firm value: Evidence on outside top executives as expertindependent directors. Corporate Governance: An International Review, 16(1), 16-31. DOI: http://dx.doi.org/10.1111/j.1467-8683.2008.00662.x

Claessens, S., \& Yurtoglu, B. B. (2013). Corporate governance in emerging markets: A survey. Emerging

Markets Review, 15, 1-33.

Conyon, M. J., \& Peck, S. I. (1998). Board size and corporate performance: evidence from European countries. The European Journal of Finance, 4(3), 291-304. DOI: http://dx.doi.org/10.1080/135184798337317 
Darko, J., Aribi, Z. A., \& Uzonwanne, G. C. (2016). Corporate governance: the impact of director and board structure, ownership structure and corporate control on the performance of listed companies on the Ghana stock exchange. Corporate Governance, 16(2), 259-277.

De Andres, P., \& Vallelado, E. (2008). Corporate governance in banking: The role of the board of directors. Journal of Banking \& Finance, 32(12), 2570-2580.

Demirgüç-Kunt, A., Feyen, E., \& Levine, R. (2012). The evolving importance of banks and securities markets. The World Bank Economic Review, 22-35.

Eisenberg, T., Sundgren, S., \& Wells, M. T. (1998). Larger board size and decreasing firm value in small firms1. Journal of financial economics, 48(1), 35-54. DOI: http://dx.doi.org/10.1016/S0304-405X(98)00003-8

Elsayed, K. (2007). Does CEO duality really affect corporate performance? Corporate Governance: An International Review, 15(6), 1203-1214.

Erkens, D. H., Hung, M., \& Matos, P. (2012). Corporate governance in the 2007-2008 financial crisis: Evidence from financial institutions worldwide. Journal of Corporate Finance, 18(2), 389-411.

Fama, E. F., \& Jensen, M. C. (1983). Agency problems and residual claims. Journal of law and economics, 327-349.

Fethi, M. D., \& Pasiouras, F. (2010). Assessing bank efficiency and performance with operational research and artificial intelligence techniques: A survey. European Journal of Operational Research, 204(2), 189-198. DOI: http://dx.doi.org/10.1016/j.ejor.2009.08.003

Florackis, C., Kanas, A., \& Kostakis, A. (2015). Dividend policy, managerial ownership and debt financing: A nonparametric perspective. European Journal of Operational Research, 241(3), 783-795. DOI: http://dx.doi.org/10.1016/j.ejor.2014.08.031

Fosu, S. (2013). Capital structure, product market competition and firm performance: Evidence from South Africa. The quarterly review of economics and finance, 53(2), 140-151.

Ganguli, S. K., \& Guha Deb, S. (2016). Board Composition, Ownership Structure and Firm Performance: New Indian Evidence in a Unique Regulatory Environment.

Geske, R., Subrahmanyam, A., \& Zhou, Y. (2016). Capital structure effects on the prices of equity call options. Journal of financial economics, 121(2), 231-253.

Ghana Statistical Service Bulletin, 2015.

Gill, A., Biger, N., \& Mathur, N. (2011). The effect of capital structure on profitability: Evidence from the United States. International journal of management, $28(4), 3$.

Gitundu, E. W., Kisaka, S. E., Kiprop, S. K., \& Kibet, L. K. (2016). The Effects of Ownership and Corporate Governance Reforms on Efficiency of Privatized Companies in Kenya. International Journal of Economics and Financial Issues, 6(1).

Haan, J., \& Vlahu, R. (2016). Corporate governance of banks: A survey. Journal of Economic Surveys, 30(2), 228277.

Harrison, J. S., \& Freeman, R. E. (1999). Stakeholders, social responsibility, and performance: Empirical evidence and theoretical perspectives. Academy of Management Journal, 42(5), 479-485.

Hasan, M. B., Ahsan, A. M., Rahaman, M. A., \& Alam, M. N. (2014). Influence of capital structure on firm performance: Evidence from Bangladesh. International Journal of Business and Management, 9(5), 184.

Hau, H., \& Thum, M. (2009). Subprime crisis and board (in-) competence: private versus public banks in Germany. Economic Policy, 24(60), 701-752.

Hsu, W.-Y., \& Petchsakulwong, P. (2010). The impact of corporate governance on the efficiency performance of the Thai non-life insurance industry. Geneva Pap R I-Iss P, 35(S1), S28-S49. doi:

http://dx.doi.org/10.1057/gpp.2010.30

Huang, L.-Y., Lai, G. C., McNamara, M., \& Wang, J. (2011). Corporate governance and efficiency: Evidence from U.S. property-liability insurance industry. Journal of Risk and Insurance, 78(3), 519-550. DOI: http://dx.doi.org/10.1111/j.1539-6975.2011.01410.x

Huang, L. Y., Lai, G. C., McNamara, M., \& Wang, J. (2011). Corporate governance and efficiency: evidence from US property-liability insurance industry. Journal of Risk and Insurance, 78(3), 519-550.

Huther, J. (1997). An empirical test of the effect of board size on firm efficiency. Economics Letters, 54(3), 259-264.

Iannotta, G., Nocera, G., \& Sironi, A. (2007). Ownership structure, risk and performance in the European banking industry. Journal of Banking \& Finance, 31(7), 2127-2149.

Ibe, S. O. (2013). the Impact of Liquidity Management on the Profitability of Banks in Nigeria. Journal of Finance and Bank Management, 1(1), 37-48.

Ince, I. (2012). Finance contribution to GDP- another sleight of hand? Critical legal thinking, Law and the Political.

Isik, I., \& Hassan, M. K. (2002). Cost and profit efficiency of the Turkish banking industry: An empirical investigation. The Financial Review, 37(2), 257-279.

Isshaq, Z., \& Bokpin, G. A. (2012). Expansion and Efficiency in Banking: Evidence from Ghana. Managerial and Decision Economics, 33(1), 19-28. DOI: 10.1002/mde.1556 
Jaffry, S., Ghulam, Y., \& Cox, J. (2013). Trends in efficiency in response to regulatory reforms: The case of Indian and Pakistani commercial banks. European Journal of Operational Research, 226(1), 122-131. DOI: http://dx.doi.org/10.1016/j.ejor.2012.11.002

Jensen, M. C. (1986). Agency costs of free cash flow, corporate finance, and takeovers. The American economic review, 76(2), 323-329.

Jensen, M. C., \& Meckling, W. (1976). Theory of the firm: Managerial behaviour, agency costs and capital structure. Journal of financial economics, 3, 305-360.

Jensen, M. C., \& Meckling, W. H. (1976). Theory of the firm: Managerial behaviour, agency costs and ownership structure. Journal of financial economics, 3(4), 305-360. DOI: http://dx.doi.org/10.1016/0304$\underline{405 X(76) 90026-X}$

Kader, H. A., Adams, M., Hardwick, P., \& Kwon, W. J. (2014). Cost efficiency and board composition under different takaful insurance business models. International Review of Financial Analysis, 32(0), 60-70. DOI: http://dx.doi.org/10.1016/j.irfa.2013.12.008

Khiari, W., Karaa, A., \& Omri, A. (2007). Corporate governance efficiency: an indexing approach using the stochastic frontier analysis. Corporate Governance: The international journal of business in society, 7(2), $148-161$.

Köksal, B., \& Orman, C. (2015). Determinants of capital structure: evidence from a major developing economy. Small Business Economics, 44(2), 255-282.

Kraus, A., \& Litzenberger, R. H. (1973). A state-preference model of optimal financial leverage. The Journal of Finance, 28(4), 911-922.

Krause, R., Semadeni, M., \& Cannella, A. A. (2014). CEO duality: A review and research agenda. Journal of Management, 40(1), 256-286. DOI: http://dx.doi.org/10.1177/0149206313503013

Lake, E. (2013). Financial risks and profitability of commercial banks in Ethiopia. Unpublished Doctoral dissertation, Addis Ababa University Addis Ababa, Ethiopia.

Lam, T. Y., \& Lee, S. K. (2008). CEO duality and firm performance: evidence from Hong Kong. Corporate Governance: The international journal of business in society, 8(3), 299-316. DOI: http://dx.doi.org/10.1108/14720700810879187

Li, Y. (2007). Determinants of banks' profitability and its implication on risk management practices: Panel evidence from the UK in the period 1999-2006.

Liu, J. S., Lu, L. Y. Y., \& Lu, W.-M. (2016). Research fronts in data envelopment analysis. Omega, 58, 33-45. DOI: http://dx.doi.org/10.1016/j.omega.2015.04.004

Lu, W.-M., Wang, W.-K., Hung, S.-W., \& Lu, E.-T. (2012). The effects of corporate governance on airline performance: Production and marketing efficiency perspectives. Transportation Research Part E: Logistics and Transportation Review, 48(2), 529-544. DOI: http://dx.doi.org/10.1016/j.tre.2011.09.003

Maer, L., \& Broughton, N. (2012). Financial Services: contribution to the UK economy. House of Commons Standard Note, SN/EP/06193.

Majumdar, S. K., \& Chhibber, P. (1999). Capital structure and performance: Evidence from a transition economy on an aspect of corporate governance. Public Choice, 98(3), 287-305.

Makokha, A. W. (2014). The effect of corporate governance on the financial performance of insurance companies in Kenya. The University Of Nairobi.

Malik, A., Thanh, N. M., \& Shah, H. (2016). Effects of ownership structure on bank performance: evidence from Vietnamese banking sector. International Journal of Business Performance Management, 17(2), 184-197.

Mallin, C., Farag, H., \& Ow-Yong, K. (2014). Corporate social responsibility and financial performance in Islamic banks. Journal of Economic Behavior \& Organization, 103, Supplement(0), S21-S38. DOI: http://dx.doi.org/10.1016/j.jebo.2014.03.001

Mark, S., Philip, L., \& Adrian, T. (2009). Research methods for business students. Harlow: Prentice-Hall.

McConnell, J. J., \& Servaes, H. (1990). Additional evidence on equity ownership and corporate value. Journal of Financial Economics, 27(2), 595-612. DOI: http://dx.doi.org/10.1016/0304-405X(90)90069-C

Mehran, H., Morrison, A. D., \& Shapiro, J. D. (2011). Corporate governance and banks: What have we learned from the financial crisis? FRB of New York Staff Report(502).

Mersland, R., \& Øystein Strøm, R. (2009). Performance and governance in microfinance institutions. Journal of Banking \& Finance, 33(4), 662-669. DOI: DOI: 10.1016/j.jbankfin.2008.11.009

Min, B. S., \& Bowman, R. G. (2015). Corporate governance, regulation and foreign equity ownership: Lessons from Korea. Economic Modelling, 47(0), 145-155. DOI: http://dx.doi.org/10.1016/j.econmod.2015.02.030

Minton, B., Taillard, J., \& Williamson, R. (2010). Board composition, risk-taking and value: Evidence from financial firms. SSRN Electronic Journal.

Modigliani, F., \& Miller, M. H. (1958). The cost of capital, corporation finance and the theory of investment. The American economic review, 48(3), 261-297. 
Morck, R., Shleifer, A., \& Vishny, R. W. (1988). Management ownership and market valuation: An empirical analysis. Journal of Financial Economics, 20, 293-315. DOI: http://dx.doi.org/10.1016/0304$\underline{405 X(88) 90048-7}$

Najjar, N. J. (2012). The impact of corporate governance on the insurance firm's performance in Bahrain. International Journal of Learning and Development, 2(2), 1-17.

Naushad, M., \& Malik, S. A. (2015). Corporate Governance and Bank Performance A Study of Selected Banks in GCC Asian Social Science, 11, 226-234.

Nguyen, T. T., \& Oraintara, S. (2008). The shiftable complex directional pyramid—Part I: Theoretical aspects. IEEE Transactions on Signal Processing, 56(10), 4651-4660.

Nielsen, S., \& Huse, M. (2010). The contribution of women on boards of directors: Going beyond the surface. Corporate Governance: An International Review, 18(2), 136-148.

Nikoo, S. F. (2015). Impact of Capital Structure on Banking Performance: Evidence from Tehran Stock Exchange. International Research Journal of Applied and Basic Sciences, 9(6), 923-927.

Ntim, C. G., Lindop, S., \& Thomas, D. A. (2013). Corporate governance and risk reporting in South Africa: A study of corporate risk disclosures in the pre-and post-2007/2008 global financial crisis periods. International Review of Financial Analysis, 30, 363-383.

Ohene-Asare, K., \& Asmild, M. (2012). Banking efficiency analysis under corporate social responsibilities. International Journal of Banking, Accounting and Finance, 4(2), 146-171. DOI: 10.1504/ijbaaf.2012.048331

Öztekin, Ö. (2015). Capital structure decisions around the world: Which factors are reliably important? Journal of Financial and Quantitative Analysis, 50(03), 301-323.

Öztekin, Ö., \& Flannery, M. J. (2012). Institutional determinants of capital structure adjustment speeds. Journal of financial economics, 103(1), 88-112.

Panda, H. (2016). Ownership Structure of Banks and Its Effect on Their Performance. Available at SSRN 2769170.

Paradi, J. C., \& Zhu, H. (2013). A survey on bank branch efficiency and performance research with data envelopment analysis. Omega, 41(1), 61-79. DOI: http://dx.doi.org/10.1016/j.omega.2011.08.010

Pathan, S. (2009). Strong boards, CEO power and bank risk-taking. Journal of Banking \& Finance, 33(7), 13401350.

Peterson, C. L. (2006). Preemption, agency cost theory, and predatory lending by banking agents: are federal regulators biting off more than they can chew. Am. UL Rev., 56, 515.

Pfeffer, J., \& Salancik, G. R. (1978). The external control of organizations: A resource dependence perspective. New York: Harper and Row.

Phung, D. N., \& Le, T. P. V. (2013). Foreign ownership, capital structure and firm performance: empirical evidence from Vietnamese listed firms. IUP Journal of Corporate Governance, 12(2), 40.

Pi, L., \& Timme, S. G. (1993). Corporate control and bank efficiency. Journal of Banking \& Finance, 17(2), 515530.

Poudel, R. P., \& Hovey, M. (2012). Corporate governance and efficiency in Nepalese commercial banks. Available at SSRN 2163250.

PriceWaterHouse Cooper (2014). Ghana banking survey 2014. Accra, Author.

Provan, K. G. (1980). Board power and organizational effectiveness among human service agencies. Academy of Management Journal, 23(2), 221-236.

Pugliese, A., Minichilli, A., \& Zattoni, A. (2014). Integrating agency and resource dependence theory: Firm profitability, industry regulation, and board task performance. Journal of Business Research, 67(6), 11891200. DOI: http://dx.doi.org/10.1016/j.jbusres.2013.05.003

Reddy, K., Locke, S., \& Fauzi, F. (2013). Relevance of corporate governance practices in charitable organisations: A case study of registered charities in New Zealand. International Journal of Managerial Finance, 9(2), $110-132$.

Salim, M., \& Yadav, R. (2012). Capital structure and firm performance: Evidence from Malaysian listed companies. Procedia-Social and Behavioral Sciences, 65, 156-166.

Salteh, H. M., Ghanavati, E., Khanqah, V. T., \& Khosroshahi, M. A. (2012). Capital structure and firm performance: Evidence from Tehran stock exchange. International Proceedings of Economics Development \& Research, 43, 225-30.

Sanders, W. G., \& Carpenter, M. A. (1998). Internationalization and firm governance: The roles of CEO compensation, top team composition, and board structure. Academy of Management Journal, 41(2), 158178.

Saunders, M. L., \& Lewis, P. (2009). P. and Thornhill, A.(2009). Research methods for business students, 4.

Saunders, M. N., Saunders, M., Lewis, P., \& Thornhill, A. (2011). Research methods for business students (5 ed.). India: Pearson Education. 
Schepens, G. (2016). Taxes and bank capital structure. Journal of financial economics, 120(3), 585-600.

Schindler, P. S., \& Cooper, D. R. (2005). Marketing research: Tata McGraw-Hill Education.

Shleifer, A., \& Vishny, R. W. (1997). A survey of corporate governance. The journal of finance, 52(2), 737-783.

Singh, M., \& Davidson III, W. N. (2003). Agency costs, ownership structure and corporate governance mechanisms. Journal of Banking \& Finance, 27(5), 793-816.

Smith, J. A. (2004). Reflecting on the development of interpretative phenomenological analysis and its contribution to qualitative research in psychology. Qualitative research in psychology, 1(1), 39-54.

Spira, L. F., \& Bender, R. (2004). Compare and contrast: Perspectives on board committees. Corporate Governance: An International Review, 12(4), 489-499. DOI: http://dx.doi.org/10.1111/j.1467-8683.2004.00389.x

Sundaram, A. K., \& Inkpen, A. C. (2004). Stakeholder theory and "The corporate objective revisited": A reply. Organization Science, 15(3), 370-371.

Suviranta, B. (1933). " The Shiftability Theory" of Bank Liquidity.

Tafri, F. H., Hamid, Z., Meera, A. K. M., \& Omar, M. A. (2009). The impact of financial risks on profitability of Malaysian commercial banks: 1996-2005. Strategies, 232, 2111.

Tomar, S., \& Bino, A. (2012). Corporate governance and bank performance: evidence from Jordanian banking industry. Jordan Journal of Business Administration, 8(2).

Tornyeva, K., \& Wereko, T. (2012). Corporate governance and firm performance: Evidence from the insurance sector of Ghana. European Journal of Business and Management, 4(13), 95-112.

Tsorhe, J. S., Aboagye, A. Q., \& Kyereboah-Coleman, A. (2011). Corporate governance and bank risk management in Ghana. University of Ghana Business School.

Tudose, M. B. (2012). Capital structure and firm performance. Economy Transdisciplinarity Cognition, 15(2), 76.

Wahba, H. (2014). Capital structure, managerial ownership and firm performance: evidence from Egypt. Journal of Management \& Governance, 18(4), 1041-1061.

Wang, W.-K., Lu, W.-M., \& Lin, Y.-L. (2012). Does corporate governance play an important role in BHC performance? Evidence from the U.S. Economic Modelling, 29(3), 751- $760 . \quad$ DOI: http://dx.doi.org/10.1016/j.econmod.2012.01.021

Wei, G. (2007). Ownership structure, corporate governance and company performance in China. Asia Pacific Business Review, 13(4), 519-545. DOI: http://dx.doi.org/10.1080/13602380701300130

Wilmarth Jr, A. E. (2007). 6. Conflicts of interest and corporate governance failures at universal banks during the stock market boom of the 1990s: the cases of Enron and WorldCom. Corporate Governance in Banking: A Global Perspective, 97.

Yeh, C.-P., Wang, K.-M., \& Chai, K.-C. (2010). Measuring the efficiency of securities companies by corporate governance in a financial holding and non-financial holding system. Expert Systems with Applications, 37(6), 4671-4679. DOI: DOI: 10.1016/j.eswa.2009.12.041

Yin, G. K. (1991). Of Indianapolis Power and Light and the Definition of Debt: Another View. Va. Tax Rev., 11, 467.

Yulivan, I., \& Hadi, A. R. A. (2016). The Influence of Financial Performance, Capital Structure and Macroeconomic Factors on Firm ${ }^{-}{ }^{-}$V Value" C Evidence from Textile Companies at Indonesia Stock Exchange. Applied Finance and Accounting, 2(2), 18-29.

Zeitun, R., \& Gang Tian, G. (2007). Does ownership affect a firm's performance and default risk in Jordan? Corporate Governance: The international journal of business in society, 7(1), 66-82.

Zhang, X. (2016). Does Capital Structure Affect Firm Performance? Analysis of Panel Threshold Effect in the Case of GEM Listing Corporation. 한중경제문화연구, 7, 83-101.

Zheka, V. (2005). Corporate governance, ownership structure and corporate efficiency: the case of Ukraine. Managerial and Decision Economics, 26(7), 451-460. DOI: 10.1002/mde.1258 